\title{
ロボット介在活動における物語生成 一有料老人ホームにおけるペット型ロボットを用いた活動の事例一
}

加藤 謙介介渥
大阪大美

\section{要 約}

本研究では，高齢者に対するロボット介在活動（Robot Assisted Activity: RAA）の事例を取り上げ，RAA を，ロボットをめぐる物語の共同的承認の過程であるとして検討した。筆者らは，有料老人ホームに入所す る高齢者を対象とした，ペット型ロボットを用いた RAA を実施し，参与観察するとともに，RAA 実施中にお ける参加者群の相互作用を，定量的・定性的に分析した。定性的分析の結果，RAA 時には，対象となった高 齢者の夕ではなく，施設職員や RAA の進行係等，RAA の参加者全員が，ペット型ロボットの挙動に対して独 自の解釈を行い，それを共同的に承認しあう様子が見出された。また，定量的分析の結果，RAA 実施中にお ける参加者群の「集合的行動」のうち, 最も頻度が多かったのが, 「ロボットの動きを参加者群が注視しなが ら，発話を行う」というパターンであることが明らかになった。筆者らは，RAAを，参加者によるロボット の挙動に対する心の読み取り，及びその解釈の共同的承認を通して物語が生成され，既存の集合性とは異な る集合性，＜異質性＞が生成される過程であると考察した。

キーワード：ロボット介在活動，ペット型ロボット，心の読み取り，物語生成，＜異質性＞

\section{はじめに : ケア場面におけるロボットの活用}

近年，日本において，ロボットに対する関心が高まり つつある（白井・浅田，2001）。従来，福祉・医療分野に おいても，様々なロボットの構想・開発が行われてきた (e.g., 橋野，1996; 加藤，1993)。しかし，これまでその多 くは，歩行支援（藤江，1996）や多機能動力義足（藤本， 1996），食事搬送システムロボット（藤崎・内山，1996）， 食事支援マニュピレータ（手嶋，1996）など，ロボット が，対象者の生活を物理的・直接的に支援するような発 想に基づく開発であった。

ところが，近年では，ペット型ロボットのように，物 理的な支援は行わないが, エンターテインメントや心理
的な支援を目的とするようなロボットの開発・販売が進 んでいる。例えば, 柴田（1999）は, 労働の補助ではな く, 人のメンタルな部分にコミットし，人の心を豊かに し，心を瘉すことを目的に「「ンタルコミットロボット」 の構想・開発を行っている。また, 藤田（1999）は, 自 律型ロボットのエンターテインメントーの応用を企図 し、「ロボットをいかに生きているかのように見せるか」 という課題を, 「いかに複雑な反応と行動をロボットにさ せるか」に置き換え，16の関節，外部センサーの補強， 内部状態による反応変化のプログラミングを組み込んだ ペット型ロボットを開発した。藤田の研究に基づき, 株 式会社 SONY が開発したのが, 現在, ペット型ロボット の代表的存在として注目を集めている 4 足歩行型ロボッ

謝辞 : 本研究を進めるに当たって, 有料老人ホーム $\mathrm{K}$ の職員，ならびに利用者の方々には，多大なるご協力を賜りま した。この場を借りて，厚く御礼申し上げます。また，本研究においては，三井住友海上福祉財団より，研究 助成金（平成 13 年度研究助成・高齢者関係）を賜りました。重站て，御礼申し上げます。 
ト「AIBO」である1）。

ペット型ロボットへの社会的関心が高まるとともに， ロボットを，実際のケアの場面で活用する事例が報告さ れはじめている。ペット型ロボットは, その形態が動物 に似ていることもあり，動物介在活動（Animal Assisted Activity: AAA）（e.g., 横山，1996）と同様な手法で, 治療 場面で試用されつつある。横山（2002）は, 動物介在活 動を模したロボットの利用法を, ロボット介在活動 (Robot Assisted Activity: RAA) と名付けている。他に妥 当な呼称がないことや, RAA という呼び方が実践の中で 定着しつつあることを鑑み, 本稿でも, ロボットをケア やレクリエーションの場面に介在させる活動を，ロボッ 卜介在活動（以下，RAA）と呼ぶこととする。

ロボットを用いたケアの試みについては, そもそも一 般に入手可能なロボットの登場がごく最近だったことも あり, 研究・実践例ともに未だ数は多くはない。しかし, 小児病棟や高齢者施設などの医療・介護施設における研 究・実践例は, 徐々に報告され始めている。例えば, 横 山・玉井・太田・高橋・長谷川・赤西・中村・太田 (2001) は，小览病棟において AIBO を用いた RAA を行い，治療 場面におけるロボットの導入の可能性を示唆した。また, 横山（2002）は，小児病棟や高齢者施設での RAA に対す る観察から，人とのふれあいにおける動物，ロボットの 「効果」について, 「刺激 - 安定」仮説を提唱し, ペット動 物と比較してロボットは, 導入時の刺激は大きいが, 対 象者の心の安定を導くには至っていないと考察してい る。この他, 高齢者施設での研究例も報告され始め（e.g., Wada, Shibata, Saito, \& Tanie, 2002）, 橋本・浜田・赤澤 （2001）は, 高齢者施設においてロボットと高齢者との相 互作用を観察し, ロボットが「話題提供者」としての役 割を果していることを論じている。

ペット型ロボットの動作は, 現状では, 動物の動作と かなり異なるが，訓練に要するコストや衛生面の管理と いった点での簡便さが, 治療場面にロボットを介在させ る誘因となりうるであろう。しかし, 現時点では, RAA が対象者個々人に対して与える影響についての研究が多 く, RAA の場全体を捉え, 参加者全体の相互作用を検討 したものはほとんど見受けられない。さらに, ロボット を, 活動の中でどのように介在させるかという実践的な プログラムの開発も残された課題となっている。

\section{本研究の理論的背景}

さて，ロボットと人との交流場面では，人間がロボッ トの仕草に対して盛んに意味付けを行っていることが報 告されている。横山（2002）は, RAA 場面において, 対 象となった子供や高齢者が, ロボットの挙動に対して 様々な意味付けをしている様子を報告している。特に, 横 山の観察した小坚病棟の事例では, RAA に参加した患児 が，一緒に参加している他の患児の目を見ながら，ペッ ト型ロボットとふれあい, その行動に解釈を行っている 様子が報告されている。また, ペット型ロボットAIBO に ついて, 佐部・藤田（2000）は, 「ユーザが自分なりに都 合よく解釈を与えて」いると述べている。さらに, 柴田 （2000）は, 「感情的人工生物（= 感情を持っているかの ようなロボット)」の開発を進める中で, ロボットの動き が, 製作者の意図とは関係なく, 状況や文脈に依存して, それと触れ合っている人によって「勝手に解釈」されて いることを述べている。

このように，人間側の「解釈」が，対象との相互作用 を特徴付ける事態は, 人と動物の関係においても観察さ れている。藤崎（2002）は, ペットと飼主との相互作用 を検討し, 飼主が, ペットの内的状態を解釈し, ペット に対して「心の読み取り」を行うことで, ペット - 飼主間 の関係を成立させていることを考察している。人間が, 対 象（ロボット）の行動に解釈を施し，あたかも「心」が 存在するかのように交流を図ることは，RAAを考察する 際に重要な示唆を与えるものであると考えられる。

このような先行研究は, 人とロボットとのふれあいが, 単に対象となった人々にのみ変化をもたらすものではな く, ロボットを中心にして，RAAに参加する人々が，集 合的な行動をとり行う過程であることを示唆している。 即ち, RAA は, ロボットという存在をめぐり, 当該集合 体の集合性（杉万，2001）が変容する過程であると考え られる。集合性について, 楽学舎（2000）は，「ある集合 体をその環境も含めて一つの全体として見た場合に見ら れる，全体的性質」としている。杉万（2001）は, 集合 性の 2 つの側面として,「集合的行動」と「コミュニケー ション」を挙げている。前者は, 「集合体を一つの全体と して観察したときに観察できる動き(行動)」(p. 645) で あり，これには，いわゆる物理的環境（物的環境）や制 度や役割のような, 繰り返され定型化した「集合的行動」

1）AIBO に関しては，公式のウェブサイトが開設され，情報が公開されている。現在までに，SONY は 6 種類の AIBO を生産・出荷している。正確な出荷台数については, SONY は明らかにしていないが，一説には国内で 14 万台が出荷されていると言われている。 http://www.jp.aibo.com/ 
（“もの” 的環境）も含まれる。一方後者は，「規範や雾囲 気を創出, 維持, 変容し, 消滅させる一連のプロセス」 （p. 646）とされている。規範や雾囲気とは，「集合体の身 体に対して妥当な現前や行為を支持寸る操作」(p.646) と されているが, 規範は言語的に表現可能, 雰囲気は言語 的に表現不可能という違いがある。本稿では, これらの 意味で用いる場合, 集合的行動を「集合的行動, コミュ ニケーションを「コミュニケーション」と表記する。

グループ・ダイナミックスの観点から見ると, 施設に おける RAA の導入・実施の過程は, 施設という集合体の 既存の集合性が，＜異質性＞出現によって変容する過程 であると位置付けることができよう。異質性とは, ある 集合性 A とは異なる性質を持つ集合性 B のことを指す （楽学舎，2000）。ある集合性 A と，A とは異なる集合性 B があるとき, 両者が完全に異質である場合, 集合性 A・ B には変化は生じない。しかし, 何らかの理由によって, 集合性 $\mathrm{A}$ の成員 $\mathrm{a}$ と集合性 B の成員 $\mathrm{b}$ を包む新たな集合 性 X が生成されることがある。新たな集合性 X は, 既存 の集合性 A・B の性質を部分的に有しつつも, 異なる性 質を持った集合性である。既存の集合性 $\mathrm{A} ・ \mathrm{~B}$ は, この 集合性 Xの出現を通して変容する。本稿では, この異質 な集合性 Xのことをく異質性＞と表記する。

同様の事例としては, 動物介在療法の実践例が挙げら れる。加藤・渥美 (2002) は, 老人性痴呆疾患治療病棟 において実施された, 動物介在療法の一種, ドッグ・セ ラピーを検討した。加藤らは, 動物介在療法の実践が, 対 象者個々人にのみ変化をもたらすのではなく, 動物介在 療法が実施される施設の職員や，それを実施するボラン ティアらにも影響を与える, 優れて集合的な事態である と捉えて検討を行っている ${ }^{2)}$ 。加藤らの研究によれば, 動 物介在療法は, それに参加した人々全体を包む場のく表 情>（廣松，1989）が変化したことにより, 既存の施設 全体の集合性に変容がもたらされる過程であるとされて いる。ここで言うく表情>とは, 廣松（1989）が，「如実 の環境世界的現相は本源的に情動的価值性を“懐胎” せ る表情性現相である (pp. 17)」と述べているように, 我々 の前に現前する世界全てが “帯びている” 性質のことで ある。杉万（2001）の集合性の理論に当てはめると，＜表 情>とは,「コミュニケーション」における雾囲気に該当 する。ここで,「場の＜表情 $>$ の変化」として記述された
事態が, 既存の集合性における<異質性 >の生成過程であ る。加藤らの研究では, 動物介在療法の実践を通して生 成された<異質性 >が, 当該集合体の成員にとって, 場の <表情＞の変化として感得されたことが報告されている。

現時点で, RAA が, 動物介在療法や動物介在活動の方 法論をほぼそのまま踏襲して実践されていることを鑑み ると, 特に施設ケアにおける RAA もまた, 既存の集合体 の集合性に，ロボットをめぐってく異質性＞が生成され る過程である, と言えるだろう。誤解のないように述べ おくと, RAAにおける<異質性>の生成とは, 既存の集 合性 $\mathrm{A}$ に, ロボットという「異質な存在」が単に加算さ れることを意味寸るのではない。もちろん，現状では， ペット型ロボットは, 社会的に見れば新奇で異質な存在 であると言える。しかし，＜異質性＞の生成とは，その ような新奇で異質な存在であるロボットをめぐって, 当 該集合体において様々な「集合的行動」「コミュニケー ション」が生成・維持・変容され, 新たな集合性 X が生 成される過程のことを指寸。この意味で, RAA は, グルー プ・ダイナミックスの研究対象として, まさに相応しい 事例であると考えられる。

本節では, RAAの実践場面を, 一つの全体として捉え て検討寸るための理論的観点を紹介寸る。先に触れたよ うに, RAAにおいては, 参加者が, 機械やロボットの動 きを「都合よく」解釈することが報告されている。また, 特に集団を対象とした RAAの場合, ロボットと触れ合う 参加者が, 他の参加者のことを気にしながら, RAAを楽 しむ様子も報告されている。本研究で筆者らが観察した 事例においてもまた, 参加者に同様の振る舞いが見受け られた。RAAにおける参加者とロボットとの相互作用を 検討するための理論的基盤として, 人が対象（物）に「心」 のようなものを読み取ってしまう営み(「心の読み取 り」), 及び，人々による解釈の共有を通して「現実」が 構成される過程（「物語生成」）の 2 つを紹介寸る。

\section{人と機械との相互作用：「心の読み取り」と物語生成}

RAA 場面における人とロボットとの相互作用を検討す る際に, まずは, 古典的な人工知能研究やロボット研究 が参考になると考えられる。これらの先行研究では, ご く簡単な機構で反応を行うロボットや人工知能に対し て, 観察者が「心」を見出してしまう例がいくつか報告

2）一般に, 動物介在療法の効果として, 身体効果, 心理効果, 社会性効果の 3 点が挙げられている (例えば, 岩 本・福井, 2001)。加藤・渥美（2002）は, 動物介在療法がもたらすとされるこれらの効果が, 対象者個々人の みに視点を置いたものであるとして批判し, 動物介在療法を, それが実施される集合体全体を視野に入れ，考 察を試みている。 
されている。例えば, Braitenberg（1984）は，「心を持つ 模型」と呼ばれる, 温度に反応するセンサーとモーター のみを取り付けた簡単な構造を持つロボットを開発し た。Braitenbergは，この模型が外界の刺激に反応して行 動する様子を観察した人が，刺激から逃げる模型を『臆 病』, 刺激に近づく模型を『攻撃的』であると見做すこと を報告している。また，Weizenbaum（1976）は，単純な ルールに基づいて，被験者の問いに応答するコンピュー タ・プログラム「イライザ」と「ドクター」を開発した。 このプログラムは，被験者の問いに対して，あたかもロ ジャーズ派の心理臨床家のような返答を行うのだが，そ の結果, 条件によっては, 被験者はこのプログラムが人 間であると思い込み，かなりの程度このプログラムとの やり取りに従事したと報告されている。「イライザ」や 「ドクター」は, チューリング・テスト（Turing, 1950）に 合格したと言われている。こうした機械やプログラムの 特徵としては, 限りなく人間に近い心的情報処理システ ムが内蔵されているわけではなく, むしろ非常に簡単な 構造やルールに基づいて行動・反応していることが挙げ られる。

これらの知見で興味深い点は, 例えば刺激から「逃げ る」行動や，「適当な」相槌を打つといった振る舞いによ り，観察者が，対象に「心」のようなものを見出してし まうことであろう。つまり，ロボットやコンピューター・ プログラムに，人間のような「心」が備えられていなく ても，我々は，そこに「心」を見出し，相互作用を行い うるのである。前述したペットと飼い主との相互作用の 特徵を検討した藤崎 (2002) の研究もまた, これら人工 知能研究と同じ図式で捉えることができる。藤崎 (2002) の研究における「心の読多取り」は，〈心の理論> (e.g., 子安・木下，1997）に関する諸研究を基礎においている。 しかしながら, 藤崎の研究結果は, 㛜密に言えば, <心 の理論 >と対応するものではなく, むしろ, ペット飼育 者が, 対象者（動物）に対して「心」を措定した上で, 交 流を図る様子が考察されている。

こうした特徵, 即ち, 対象に何らかの「心」のような ものを措定して相互作用を行うことについて, 上野・西 阪（2000）は，「心をだれかに（あるいは自分に）帰属す るということ, つまり『心をすること doing mind』は，具 体的な相互行為の中で, その相互行為を進めていくため の一つのリソースにほかならない」(p. 39) と述べている。 上野・西阪の議論を踏まえれば， RAAの実施場面でしば しば観察される, 参加者らの「ロボットの振る舞いへの 解釈」という行動は, RAAの参加者が，ロボットに対し て“doing mind”を行いながら, 相互作用を継続しているこ
とを表している, と言えるだろう。本研究では, 藤崎の 解釈, 及び, 上野・西阪の議論を踏まえ, 「対象者（物） に『心』を措定すること」を,「心の読み取り」と表記する。

重要なのは，こうした対象の「心」的状態の解釈，即 ち「心の読み取り」が, ロボット等と対峙する対象者個 人の「主観的な」解釈に留まっていたのでは, 対象との 相互行為の継続が困難である, という点である。例えば, 前掲の横山（2002）は，RAAにおけるロボットの人への 影響が「刺激は強いが安定が少ない」と報告している。こ れは, ロボットとの相互行為は, RAA 当初は活発に行わ れるが, 次第に緩慢になり, 最終的に対象者がロボット に「飽きて」しまうことを表している。「心の読み取り」 は, 人とロボットとの相互作用の一端を説明しうる概念 であるが，それだけでは， RAA 場面において，人々がロ ボットをめぐって行う「集合的行動」を捉えきれないこ とを意味していると言えよう。

ここで, 物語論の議論を援用し, 「心の読み取り」に端 を発する, 人とロボットとの相互作用の特徵を, さらに 理論的に整理してみよう。言葉, 即ち我々の解釈が, 世 界を形作るという議論は, 社会構成主義の観点からすれ ば，それほど珍しいものではない。即ち，「言葉が先に あって，その言葉が指し示すようなかたちで世界が経験 される」（野口，2002）というのが, 社会構成主義の主張 である。社会構成主義の観点に立てば, 我々の生活は, 常 に，ある「物語」の中で営まれていることとなる。

しかしながら, 個人の勝手な解釈によって, 全ての経 験が社会的に構成される, というわけでは決してない。そ うした解釈は, 他人に向けて語られ, 他人の承認や批判 によって支えられ，ひとつの「物語」となった時に初め て，我々の世界に関する経験を構成することができるの である。同様の議論は, 浅野（2001）も行っている。浅 野は，物語論に関わる思想的潮流を整理した上で，物語 の効果として，1）物語を通して，現実が構成される，2） 物語を通して, 別の物語の可能性や, 物語自身がはらむ 矛盾を隠蔽する, の 2 点を挙げている。そして, 物語が 生成されるためには，他人との相互作用が必要不可欠で あることを強調している。ある言説や解釈が他者に向け て語られ，それが他者による批判や承認を経て，ある集 合体の中で「当たり前の事柄」となるのと相即的に，そ の言説や解釈は「物語」としての効果を持つことになる。 他者との相互作用の中で「物語」が生成される事態を, 麻生（1996）は，「物語の共同的承認」という言葉で説明 している。麻生は, 乳幼児がふり遊びを通して象徵化機 能を発展させることを, 膨大な数の事例から検討してい るが, その際に, 必ず, 周囲の大人の「手助け」が関わっ 
ていることを指摘している。例えば，子供が「サンタク ロース」の存在を信じるためには, 他者, 特に周囲の大 人が，サンタクロースに関わる「物語」を共同で承認し， 共に構築する必要があると論じている。さらに重要なの は，現実（リアリティ）はただひとつ存在するのではな く, 物語（ファンタジー）という形を取って, 複数存在 しうる，という麻生の指摘である。麻生は，「『現実』を 共有寸るとは，その意味で，『現実』という『物語』を共 有することである。『現実』だから人々に『共有されてい る』のではなく, 人々に『共有されている』から『現実』 なのである」(p. 218) と述べている。麻生の主張は, あ る解釈が，他者とともに共同的に承認されることを通し て「物語」となり，(もう一つの）「現実」としての力を 持つことを論じていると言えよう。

以上の議論を踏まえ, RAAの実施場面における参加者 の振る舞いを，集合体全体を視野に入れて検討寸るため の理論的視点を, 改めて整理してみよう。RAAの参加者 は，まず，ロボットに対して「心の読み取り」を行うこ とで，ロボットをめぐる「集合的行動」を開始すると考 えられる。しかし, この解釈は, 他者によって共同的に 承認されなければ,「物語」としての効果を発揮しえない。 RAA が進展するためには, 「心の読み取り」の結果得られ た解釈が，他の参加者によって承認され，RAAをめぐる 「物語」が生成される必要がある。 RAA における，ロボッ 卜をめぐる参加者の相互作用を，集団全体を視野に入れ て考察する際には, 「ロボットに対する『心の読み取り』 一解勫の他者による承認一物語の生成」という一連のプ ロセスが, 理論的に重要な基盤となると言えるだろう。こ のプロセスは，RAAに関わる集合体の成員が，「集合的行 動」としての「コミュニケーション」を生成する過程, 即 ち，既存の集合性にとっての<異質性＞を生成するプロ セスでもある，と考えられる。この意味で，構筑された 「物語」は, 当該集合体の集合性のうち, 特に規範と, ほ ぼ同義であると言えるだろう。

本研究では, 上記の理論的観点を踏まえ, 施設に入所 する高齢者を対象とした RAAの事例を取り上げ，検討を 試みた。具体的には，筆者ら自身によって RAA を実践す るとともに，その RAAに対して長期にわたる参与観察を 行い, RAA 実施中における参加者の相互作用を詳細に検 討することを試みた。その際，ロボットをめぐる参加者 の振る舞いを，定量的・定性的に分析するとともに，参 加者らが，ロボットという新奇な存在をめぐり，いかに して<異質性 >を生成・維持・変容せしめているかを検 討した。

\section{事例：有料老人ホームKIにおけるロボット介在活動}

本研究では, 有料老人ホーム $\mathrm{K}$ （兵庫県西宮市）にお いて実施された RAA の事例を検討した。筆者らは，施設 職員及び入所者の全面的な許可・協力の下，入所寸る高 齢者を対象とした RAA を実施した。加えて筆者らは, デ ジタルビデオカメラやフィールドノートを用い， RAA 実 施場面における参加者の会話や挙動を記録した。本研究 では, RAA 実施時における参加者群の相互作用を検討寸 るため，定性的・定量的分析手法を行った。

\section{（1）方法}

本研究において，筆者らは，(1) 有料老人ホーム $\mathrm{K} に$ おける参与観察，(2) 施設職員へのインタヴュー，(3) 有 料老人ホーム $\mathrm{K}$ における $\mathrm{RAA}$ の実践, (4) 参与観察, 及 びRAA 実践から得られた定量的・定性的データの分析手 法の開発，の 4 種類の方法を採用した。以下，それぞれ について説明する。

1-1. 有料老人ホームKにおける参与観察 $\mathrm{K}$ ホームにお ける参与観察では，1）ホームで実施された RAA に対す る参与観察，2）ホームでの通常のレクリエーションへの 参与観察，及び，3）施設職員へのインタヴュー，の3つ の方法を用いた。

1) ホームKでのRAAに対する参与観察 第一筆者は, $\mathrm{K}$ ホームにおいて, 2002 年 5 月から 2003 年 2 月まで, ほ ぼ毎週 1 回約 1 時間, 施設に入所する高齢者を対象とし た RAA に対する参与観察を行った（現在までに 25 回実 施）。主たる観察方法として, デジタルビデオカメラによ る定点観察を行い，セッション内容を記録した。加えて， 第一筆者はノートを用いて観察記録を取り，RAA セッ ション中の参加者の発言や振る舞いについて記述した。

2）ホームでの通常のレクリエーションへの参与観察

第一筆者は, 墨絵や音楽療法, 敬老会など，K ホーム で実施されているRAA以外のレクリエーションに対して も参与観察を行った (現在までに 6 回実施)。筆者は, 職 員らのレクリエーション進行を補助するとともに，ノー 卜を用いて観察記録を記述した。

1-2. 施設職員へのインタヴュー 第一筆者は, RAA に対 する参与観察, 及び, 通常のレクリエーションへの参与 観察の間に, 施設職員に対してインタヴューを実施した。 インタヴューの対象となったのは, ケアマネージャー, レ クリエーションスタッフ, 介護職員, 事務員, 施設長ら であり，特にケアマネージャーに対しては，ほぼ毎回聞 き取りを行った。インタヴューに際しては, 特に質問項 目を記した用紙などは用いなかったが，RAA 実施中にお 
ける参加者の振る舞いの特徵, RAA 実施日以外の高齢者 の状況, RAA 実施日 - 時間以外の施設の状況, 今後の RAA に対する要望, 等を中心の話題とし, インタヴュー 対象者と個別で面談を行った。実施場所は, $\mathrm{K}$ ホーム内 の事務室や休惒室等であった。なお，ミニディスク等に よる録音は許可が得られなかったので，筆者はインタ ヴュー内容をノートに記述した。

なお, RAAの直接の対象者となった高齢者に対しては, インタヴューという形では聞き取りを行わなかった。こ れは，第一筆者が RAAの実践を行う中で，高齡者自身か ら，RAAに関する高齢者の意見を十分に聞き取ることが できた，と判断されたためである。第一筆者は，RAA プ ログラムの前後, 及びプログラム中に, 高齢者に対して RAA の感想や要望などを聞き取り, 内容の一部をVTRに 記録するとともに，ノートに記述した。

1-3. 有料老人ホームKIにおるRAAの実践 第一筆 者 は, $\mathrm{K}$ ホームにおいて, 2002 年 5 月から 2003 年 2 月ま で，ほぼ毎週土曜日に約 1 時間，RAAを実施した。土曜 日は，Kホームにおいて，特別なレクリエーションプロ グラムが設定されていなかった。筆者らは，施設職員ら と協議の上，この曜日にRAA を実施することを決めた。 RAA には, SONY 製のペット型ロボットAIBO (ERS-210) 1 台に, AIBO の自律動作を可能にするプログラム「八 ローAIBO！」を組み込んで用いた。

ここで, 本事例で用いたペット型ロボットの機構, 及 び使用したプログラムについて, 簡単に説明しよう。本 事例で用いた AIBO は, SONY が 2000 年から販売を開始 した「2 代目」である。高さ約 $30 \mathrm{~cm}$, 長さ約 $25 \mathrm{~cm}$, 幅約 $15 \mathrm{~cm}$, 重さ約 $1.5 \mathrm{~kg}$ である。2 代目 AIBO は, SONY に よって，ライオンの子どもをイメージして製作されたが， 1999 年に販売された初代 AIBO が「犬型ロボット」とし て宣伝された印象が強いせいか，Kホームでは，2 代目 $\mathrm{AIBO}$ も「犬」のような形をしていると見なされた。AIBO は, 充電池によって約 1 時間半稼動することが可能となっ ている。

AIBO の動作は, AIBO-ware というソフトウェアのプロ グラムによって制御されているが, 視覚・聴覚・触覚セ ンサーを用いて $\mathrm{AIBO}$ 自体が周囲の環境をモニターし, 動

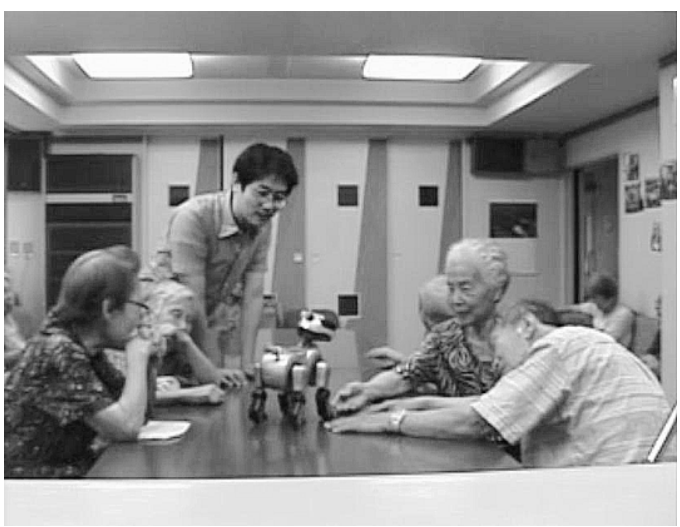

Figure 1. KホームにおけるRAAの実施場面

註）テーブル中央にあるのが，ペット型ロボットAIBO （ERS-210）である。KホームでのRAAは，このよう にAIBOをテーブルの上に置き，テーブルの周囲に入 所者らが座って, AIBOとのふれあいを楽しんだ。ま た，立ったままAIBOを見ているのは，AIBO-Master (第一筆者) である。

作を自律的に変化させるため, あたかも「生きているか のように見える」動きをすることが可能である。また, 頭 部・尾部の LED, 18 の関節の動き，電子音などによって， $\mathrm{AIBO}$ の「感情」が示されるよう設計されている。本事例 で用いたプログラム「ハローAIBO !」は, AIBO の動作 を制御する AIBO-ware の1つである。このソフトウェア を用いることで, AIBO は, 自律動作が可能になるととも に, $\mathrm{AIBO}$ 使用者からの数 10 種類の言語による呼びかけ に応じることができるようになる。

RAA の 1 セッションは, 毎回約 1 時間であり, 同施設 でレクリエーションに用いられる娛楽室において実施さ れた。Kホームでの RAA は, Figure 1 にあるように, 概 ね和やかな䨌囲気の中で行われた（Figure 1) ${ }^{3)}$ 。

RAA に参加したのは次の人々である。

1) 対象者 対象者は, 施設に入所する, 軽度の痴呆症 状を呈する高齢者であった。施設の記録によれば，参加 した高齢者は介護保険における要介護度が 2 から 5 であっ

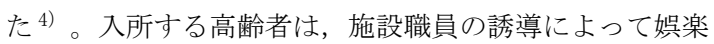
室に招かれ，毎回 5 〜 10 名の入所者が RAA に参加した。

3）写真・会話データ等, 本研究で得られた資料の発表・公刊については, 既に $\mathrm{K}$ ホームの方々と十分に議論を行 い, 快諾を得ている。

4）『要介護度 2 から 5』とは, 要介護認定等基準時間の分類を指す。要介護認定は,「介護の手間」を表す「もの さし」としての時間である「要介護認定等基準時間」を，「直接生活介助」「間接生活介助」などの基準にあて はめ, 痴呆性高齢者の指標を加味して実施するもので,「要介護認定等に係る介護認定審査会による審査及び判 定の基準等に関寸る省令 (平成 11 年 4 月 30 日厚生省令第 58 号)」として定められている。詳細は, 厚生労働 省のウェブサイトに記載されている。 http://www.mhlw.go.jp/topics/kaigo/kentou/15kourei/sankou3.html 


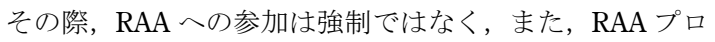
グラム中の途中退出も入所者の自由であった。なお, 同 施設での RAA 実施前まで, 対象者は誰も AIBO を直接見 たことはなく, また, 知っていた人もほとんどいなかっ た。後述するように, 継続して RAAに参加した入所者は, 5 〜 6 名であった。

2) 施設職員 RAA 時には, ケアマネージャーやレクリ エーションスタッフ, 介護職員等の施設職員が, 随時 1 〜2名参加した。職員らは, 通常業務と並行しての参加 であったため, 常にRAAに参加していたわけではないが, RAA 参加時には, 対象者の介護や世話を行うとともに, RAA プログラムの進行を補佐した。

3) AIBO-Master “AIBO-Master”という呼称は, RAA の実践プログラムに関する先行研究 (加藤・渥美・矢守, 2001）において提唱されたものである。AIBO-Master は, 単にペット型ロボットAIBO の機能を熟知した人, とい う意味ではない。ペット型ロボットの機能を知りつつ, か つプログラムの司会進行に携わり， RAA が円滑に行われ るように努めるコーディネーターのことを指す。

第一筆者は, AIBO-Master として RAA に参加した。第 一筆者は, $\mathrm{K}$ ホームへの RAA 導入時から施設職員と協議 を重ねるなど, RAA のホーム K における RAA のコーディ ネーターを務めるとともに, RAA プログラムの進行係を 兼務した ${ }^{5)}$ 。しかし, 筆者らは, 施設職員や入所者の方々 に対して, 特に「AIBO-Master」という名称を用いて自身 の立場を説明はしなかった。

$\mathrm{K}$ ホームでの RAA プログラムは, 全セッションを通し て, 凡そ次のような流れであった。第 1 に, 施設職員の 協力の下, 入所者を娛楽室に招き, 12 人がけのテーブル に添って並べられた椅子に着席させる。第 2 に, AIBOMaster が AIBO を携えて入室し, 電源を入れてからテー ブルの上に置き, RAAの開始を入所者に告げる。第 3 に, AIBO-Master は, 起動した AIBO に「ごあいさつ」とい う命令を与え, AIBO に入所者に向けてお辞儀をさせる。 第 4 に, AIBO-Master は, 「お手」「お座り」等の命令を 与え, $\mathrm{AIBO}$ に様々な振る舞いをさせるとともに, 入所者
に対して, AIBO の背中や頭を押すと反応すること, AIBO は「お手」や「お座り」などの命令を聞くことができる こと等, AIBO の機能について, 簡単な説明をする。その 後, 入所者と $\mathrm{AIBO}$ との自由なふれあいの時間（約 10 分 間）を設ける。第 5 に, AIBO-Master は, AIBO の付属品 であるボールを取り出し, 入所者に対して AIBO がボー ルに関心を示すことを説明する。その後, 入所者にボー ルを使って AIBO と遊ぶよう促す。最後に, AIBO-Master は, 参加者に RAAの時間が終了することを告げ, 再び AIBO に「ごあいさつ」の命令を与える。

上記のようなプログラムには, 実際に施設職員に参加 してもらうとともに, プログラム終了後のインタヴュー を行うことで, 施設職員の意見を取り入れ, 常に改良を 試みた。また, 第一筆者は, プログラム進行において倫 理的な問題がないかどうかも検討するよう, 施設職員に 随時依頼し, $\mathrm{K}$ ホームでの RAA のプログラム進行に, 施 設職員の視点から見ても, 特に倫理的な問題がないこと を確認した。また, 入所者に対しても, RAA への参加は 決して強要せず, RAA の参加を嫌がる高齢者には, 無 理強いはしなかった。

1-4. 分析手法の開発 筆者らは, $\mathrm{K}$ ホームでの RAA の参与観察で得られた記録（デジタルビデオカメラによ る記録, 筆者の観察記録) について, 定性的・定量的に 分析を試みた。特に, 定量的データの分析については, 仮 説検証型の研究における位置づけとは異なり, 筆者らの 理論的観点, 及び, 観察記録等から得られた質的データ を,「新聞記事における見出し・写真」(Gergen, 1999) の ような表現力を持って説明できる「例」を示すことを目 的としている ${ }^{6)}$ 。以下, 定量的データの記録, 定量的デー タの分析, 定性的データの分析の 3 点について述べる。

1）定量的データの記録 定量的データ収集には, デジ タルビデオカメラによる記録を用いた。筆者らは, RAA 場面の撮影の際, できるだけ参加者群全体がフレーム内 に収まるよう, カメラを配置した。

筆者らは, RAA 実施中における参加者群の行動を定量 化するため，撮影した RAA 全セッションのうちから，第

5）本稿の審査の過程で, 第一筆者が, RAAの実践者であり, かつ分析者でもあるのは, データの分析や解釈の過 程に影響を及ぼしているのではないか, というご指摘を頂いた。

本研究は, 研究者と研究対象者 (当事者) との間に一線を画すことはできない, という前提に立つ。そして, 研究者（である第一筆者）が，当事者と積極的に相互作用を行い，当事者と言説を交わしながら，「共同的実 践」（杉万，2000）に取り組むことを試みた。本研究での RAAの事例は，筆者らの共同的実践の事例でもある。 しかし, だからと言って, 第一筆者の恣意的な判断で, 現場で得られたデータを加工・捏造したり, 勝手な解 釈を施すことは避けなければならない。そのため, 本研究では, データの記録を第三者とともに行ったり, デー タの分析や解釈は（直接 RAA を実施しなかった）第二・第三筆者と議論して行うなど, できるだけ，「当事者 (現場の人々，及び，RAAの実践者でもある第一筆者)」以外の視点を，分析・考察の過程に入れるよう努めた。 
Table 1

VTRデータ分析のための記録の基準

\begin{tabular}{|c|c|c|c|c|}
\hline $\begin{array}{l}\text { 参加者群の } \\
\text { 行動力テゴリ- }\end{array}$ & \multicolumn{4}{|c|}{ 記録の基準 } \\
\hline AIBO の発声 & 0 回 $=0$ & 1 回以上 = 1 & & \\
\hline AIBO の行動 & 0 回 $=0$ & 1 回以上 = 1 & & \\
\hline AIBO-Master の発声 & 0 回 $=0$ & 1 回以上 = 1 & & \\
\hline AIBO-Master の AIBO への接触 & 0 回 $=0$ & 1 回以上 = 1 & & \\
\hline AIBO-Master の AIBO への視線 & 0 回 $=0$ & 1 回以上 = 1 & & \\
\hline 高齢者の発声 & 0 人 $/ 0$ 回 $=0$ & 1 人 $/ 1$ 回 $=1$ & 2 人 $/ 2$ 回以上 $=2$ & \\
\hline 高齢者の AIBO への接触 & 0 人 $/ 0$ 回 $=0$ & 1 人 $/ 1$ 回 $=1$ & 2 人 $/ 2$ 回以上 $=2$ & \\
\hline 高齢者の AIBO への視線 & 0 人 $/ 0$ 回 $=0$ & 1 人 $/ 1$ 回 $=1$ & 2 人 $/ 2$ 回 $=2$ & $\mathrm{n}$ 人 $/ \mathrm{n}$ 回 $=\mathrm{n}$ \\
\hline 施設職員の発声 & 0 人 $/ 0$ 回 $=0$ & 1 人 $/ 1$ 回 $=1$ & 2 人 $/ 2$ 回以上 $=2$ & \\
\hline 施設職員の AIBO への接触 & 0 人 $/ 0$ 回 $=0$ & 1 人 $/ 1$ 回 $=1$ & 2 人 $/ 2$ 回以上 $=2$ & \\
\hline 施設職員の AIBO への視線 & 0 人 $/ 0$ 回 $=0$ & 1 人 $/ 1$ 回 $=1$ & 2 人 $/ 2$ 回 $=2$ & $\mathrm{n}$ 人 $/ \mathrm{n}$ 回 $=\mathrm{n}$ \\
\hline $\mathrm{RAA}$ への参加者数 & 0 人 $=0$ & 1 人 $=1$ & 2 人 $=2$ & $\mathrm{n}$ 人 $=\mathrm{n}$ \\
\hline
\end{tabular}

1 セッション（42 分）と第 13 セッション（62 分）の 2 セッションを選出した。この 2 セッションを選出した理 由は, 次の 2 点である。第 1 に, RAA という新奇な活動 が, 初めて $\mathrm{K}$ ホームに導入された際の, 参加者の相互作 用を検討する必要があったため, 第 1 セッションが選出 された。第 2 に, RAAがかなり継続して実施された後の, 参加者の相互作用を検討寸るため, 第 13 セッションが選 出された。第 13 セッションは, 本研究で適用した分析手 法が開発された時点での, 最新のセッションでもあった。

本分析では，2セッションのVTR 記録を，それぞれ 5 秒間を 1 測定単位として区切った。さらに, 観察記録等 から抽出した参加者群の 12 の行動カテゴリーについて, Table 1 にまとめた基準で, 1 測定単位中の生起頻度を記 録した（Table 1)。

本分析で検討した行動カテゴリーは, 以下の通りであ る。まず, AIBOの行動については, AIBOの「発声」と 「動き」を取り上げた。その際, 発声や動きの種類につい ては問わず，頻度のみを記録した。次に, AIBO-Master の行動については, AIBO-Masterの「発声」,「AIBO への 接触」,「AIBO への視線」の 3 種類を取り上げ, 頻度を記 録した。そして，対象者である高齢者の行動については， 対象者の「発声」,「AIBO への接触」,「AIBO への視線」
の 3 種類を取り上げ, 頻度を記録した。さらに, ケアマ ネージャーやレクリエーションスタッフなど, RAA に参 加したスタッフの行動については, スタッフの「発声」, $\lceil\mathrm{AIBO}$ 一の接触」,「AIBO への視線」の 3 種類を取り上げ, 頻度を記録した。最後に，1測定単位中における RAAの 参加人数を記録した。これは， RAA への参加・退出に制 限がなく, 1 セッション中における参加人数に変動があっ たためである。

以上のような基準で, 筆者らは, 参加者群の 12 の行動 カテゴリーを記録した。なお, 全ての行動カテゴリーに ついて, ビデオの記録からは判断しかねるものは, 全て 「不明」と処理した。また, 記録は, 第一筆者を含む 3 名 が個別に行い，一致率は $84 \%$ であった。本研究では，こ の值を踏まえつつ, 一致していなかった部分も含めて データとして扱った。これらの記録は一覧表として整理 し, 第 1 セッションは 12 列 $\times 504$ 行, 第 13 セッションは 12 列 $\times 744$ 行の記録表となった。

2）定量的データの分析 筆者らは, 上述した手続きの 結果得られた RAA参加者群の行動の定量的データについ て, カテゴリー間の交差相関係数の吟味, 再定義した数 值に基づく RAAセッション中の参加者群の行動パターン の度数分布, 及び, 再定義後の数值に基づく各行動力テ

6）本研究において，筆者らが定量的データの採集，及び分析手法の開発を行ったのは，「経験主義に基づく発見 は，ある観点における明瞭な例を生み出すことができる」（Gergen, 1999, p. 94）と考えたためである。従って， 本研究での定量的分析は, 筆者らの理論的観点を「実証」するためのものではなく, 理論を表現力をもって「例 証」するための手段として位置づけられる。また, 分析結果は, RAAをめぐる参加者らの「集合的行動」の変 化の「例」に過ぎない。 
ゴリーの生起率, の 3 種類の分析を試みた。これら全て の定量的分析には，SPSS10.0J for Windowsを用いた。以 下，分析の概略を述べる。

第 1 に, 時間差を含めた参加者間の相互作用, 即ち RAA 中の参加者群の行動を再現できるような分析手法開発の ため, 各カテゴリー間の交差相関を検討した。この分析 は, RAA セッション中における参加者群の行動の先行指 標を検討することも目的とした。つまり，この分析では， どの行動カテゴリーが, 他の行動カテゴリーに先行して 生起するかを検討することで, RAA 実施場面での「集合 的行動」を，いわば「リードする」行動を見出すことを 試みている。例えば, 交差相関検定の結果, 「AIBO の動 き」が,「参加者（高齢者）の発声」に対して, ラグ +2 で正の相関となった場合, AIBO が動いてから約 10 秒後 に，高齢者が発話を行っていることが示される。これは， 「AIBO の動き」が，「参加者の発声」という「集合的行 動」をリードし, その結果, 10 秒後に, 高齢者の発話が 生じる, という意味である。本研究では, 「AIBO の挙動 (発声・動き) と, その他の 10 項目との交差相関」「AIBOMasterの挙動（発声・接触・視線）と, 参加者の挙動（発 声・接触・視線）との交差相関」「スタッフの挙動（発 声・接触・視線） と, 参加者の挙動（発声・接触・視線） との交差相関」の，大きく 3 項目の分析を行った。なお， 検討する時間差（ラグ）は 7 測定単位（ \pm 35 秒以内の時 間）に設定した。

これを踏まえて, RAA セッション中における, 参加者 群の行動全体の傾向を検討するため, セッション中の各 項目の生起数の平均值を算出し, それに基準として, 各 項目で得られた数值を, 行動の生起数 (なし $=0$ ・有り $=1$ ) として再定義した。これは, 定量的データをさらに簡略 化することで, RAA セッション中における参加者群の行 動の全体的な傾向をとらえることを目的としている。そ の上で，第 2 , 第 3 の分析を行った。

第 2 の分析では, 1 測定単位毎の各項目の数值を, 2 進 法による 12 桁の数字とみなした。例えば， 1 測定単位中 の 12 の行動カテゴリーが, それぞれ『AIBOの発声「あ り」・AIBO の動き「なし」・AIBO マスターの発声「あ り」・AIBO マスターの AIBO への接触「なし」・AIBO マ スターの $\mathrm{AIBO}$ への視線「なし」・参加者の発声「なし」・ 参加者の $\mathrm{AIBO} \sim$ の接触「なし」・参加者の $\mathrm{AIBO} \sim$ の視
線「なし」・スタッフの発声「あり」・スタッフの $\mathrm{AIBO}$ 一 の接触「なし」・スタッフの $\mathrm{AIBO}$ への視線「なし」・AIBO までの距離「少ない」』だった場合，2進法での表記は， 『101000001000』となる。その上で, 12 桁の二進法の数值 を 10 進法の数值に変換し, 各測定単位における参加者群 全体の行動パターンを数值化した。例えば, 上記の行動 カテゴリーでの 2 進法表記（101000001000）を 10 進法の 数值に変換すると, 『2568』と表記される。これにより, 2 の 12 乗の行動パターンを記述することができる。この ような数值変換を用いて, 1 測定単位における行動パター ンを定量化し, 両セッションにおける行動パターンの度 数分布を検討した。

第 3 の分析では, 両セッション中における, 各行動力 テゴリーの生起率を検討した。これは, セッションを通 した各行動カテゴリーの生起率を見ることで, RAA セッ ション中における参加者群の行動パターンの全体の傾向 を検討するためである。

3）定性的分析 定性的データには, K ホームでの参与 観察中に収集した 3 種類の記録（デジタルビデオカメラ による RAA セッション中の記録, 筆者の観察記録, 施設 職員へのインタヴュー結果）を用いた。筆者らは，上記 3 種類のデータを用いて, K ホームにおける RAA に関す るフィールドノーツ7）を作成した。その上で，それら質 的データを, 本研究の理論的観点, 即ち人と機械との相 互行為における「心の読み取り一解釈の他者による承認 一物語の生成」の過程に基づいて整理し，RA場面にお ける, 参加者群のペット型ロボットをめぐる相互作用を, エスノグラフィとしてまとめた。

\section{2. 結果}

本研究で開発した定量的・定性的分析を行った結果, RAA セッション中における参加者群の行動について, 様々な特徵を見出すことができた。以下, それぞれの分 析結果について述べる。

2-1. 定量的分析 上述したように, 本研究では, 定量的 分析として，1）各カテゴリーの交差相関係数の吟味，2） 各測定単位における行動パターンの度数分布, 3) 両セッ ション中における各行動カテゴリーの生起率, の 3 種類 の分析を行った。以下，その概要を述べる。

1）各カテゴリーの交差相関の検定 本分析では, 各

7）日本では，通常「フィールドノート」という単数形で表記される。これに対して, Emerson, Fretz, Show (1995) は, 調査地で見聞きしたメモを「フィールドノート」とし, メモの整理や, 調查地に関する二次的資料の集積 の意味も含めたものは，「フィールドノーツ」という表記をすることで両者の区別をしている。本研究では, Emerson らに倣い，定性的データを整理したものを「フィールドノーツ」とした。 
Table 2

第1セッションにおける各行動カテゴリー間の交差相関の結果

\begin{tabular}{|c|c|c|c|}
\hline 先行指標と仮定した行動カテゴリー & 有意な結果が得られた行動カテゴリー & 相関係数（p<.05） & ラグ \\
\hline \multirow[t]{6}{*}{ AIBO の発声 } & AIBO-Master の AIBO への接触 & .138 & -1 \\
\hline & AIBO-Master の AIBO への視線 & .172 & 0 \\
\hline & 高齢者の発声 & -.187 & +2 \\
\hline & 施設職員の発声 & .119 & +6 \\
\hline & 施設職員の $\mathrm{AIBO}$ への接触 & .095 & +1 \\
\hline & 施設職員の AIBO への視線 & .095 & -6 \\
\hline \multirow[t]{9}{*}{ AIBO の動き } & AIBO-Master の発声 & -.097 & -3 \\
\hline & AIBO-Master の AIBO への接触 & -.255 & -6 \\
\hline & AIBO-Master の AIBO への視線 & .309 & 0 \\
\hline & 高齢者の発声 & -.154 & -5 \\
\hline & 高齢者の $\mathrm{AIBO}$ 一の接触 & .106 & +5 \\
\hline & 高齢者の AIBO への視線 & .256 & 0 \\
\hline & 施設職員の発声 & -.095 & -7 \\
\hline & 施設職員の AIBO への視線 & .123 & 0 \\
\hline & 参加者数 & -.103 & -4 \\
\hline \multirow[t]{2}{*}{ AIBO-Master の発声 } & 高齢者の発声 & .122 & 0 \\
\hline & 高齢者の AIBO への接触 & -.199 & -3 \\
\hline \multirow[t]{3}{*}{ AIBO-Master の AIBO への接触 } & 高齢者の発声 & -.101 & +7 \\
\hline & 高齢者の $\mathrm{AIBO}$ への接触 & -.178 & -7 \\
\hline & 高齢者の AIBO への視線 & -.297 & +7 \\
\hline \multirow[t]{2}{*}{ AIBO-Master の AIBO への視線 } & 高齢者の $\mathrm{AIBO}$ 一の接触 & -.151 & -2 \\
\hline & 高齢者の AIBO への視線 & .193 & 0 \\
\hline \multirow[t]{2}{*}{ 施設職員の発声 } & 高齢者の $\mathrm{AIBO}$ への接触 & -.099 & +7 \\
\hline & 高齢者の AIBO への視線 & .206 & +5 \\
\hline \multirow[t]{2}{*}{ 施設職員の $\mathrm{AIBO}$ への視線 } & 高齢者の発声 & -.124 & +7 \\
\hline & 高齢者の $\mathrm{AIBO}$ への視線 & -.099 & -7 \\
\hline
\end{tabular}

註）「AIBOの発声」と「施設職員の発声」を例として, Table $2 ・ 3 の$ 見方を説明する。Table 2では, 『「AIBOの発声」が 「施設職員の発声」に対し，ラグ+6で，正の相関がある』という結果が示されている。これは，「AIBOの発声」が， 「施設職員の発声」という行動に，＋6の先行指標となっていることを意味する。つまり，「AIBOの発声」が「施設 職員の発声」という行動をリードし,「AIBOの発声」後, ラグ+6（30秒後）に, 「施設職員の発声」という行動が 生じていることを示している。

セッションで 47 点の交差相関を検討した。その結果，第 1 セッションでは Table 2 に整理した 26 点で, 統計的に 有意な結果が得られた（Table 2)。

一方, 第 13 セッションでは, Table 3 に整理した 28 点 で，統計的に有意な結果が得られた（Table 3)。

Table 2 及び Table 3 に見られるように, 両セッション では, 様々な項目間において, 有意な結果を得られた。し かしながら，相関係数の值に注目すると，第 1 セッショ ンでは-.297 から.309（p<.05），第 13 セッションではー .303 から.372（p<.05）であり, 各項目間に十分に相関が
あると結論付けるには低い值であった。また，先行指標 については, 両 Table を一見して, 両セッションを通し て,「AIBOの動き」だけが, AIBO-Master, 高齢者, 施 設職員の「AIBO への視線」に影響を与えているように見 受けられる。

特に, 参加者群の「発声」に注目してみると, 第 1 セッ ションでは, AIBOの動きや発声ではなく, AIBO-Master の発声が, 高齢者の発声の先行指標となっていることが 伺える。さらに, 第 13 セッションでは, AIBO やAIBOMaster ではなく, 施設職員の発声が, 高齢者の発声の先 
Table 3

第13セッションにおける各行動カテゴリー間の交差相関の結果

\begin{tabular}{|c|c|c|c|}
\hline 先行指標と仮定した行動カテゴリー & 有意な結果が得られた行動カテゴリー & 相関係数（p<.05） & ラグ \\
\hline \multirow[t]{6}{*}{ AIBO の発声 } & AIBO-Master の AIBO への発声 & .128 & +6 \\
\hline & AIBO-Master $の \mathrm{AIBO} へ の$ 接触 & .143 & -5 \\
\hline & AIBO-Master の AIBO への視線 & .108 & +7 \\
\hline & 高齢者の発声 & -.159 & +1 \\
\hline & 高齢者の視線 & .170 & +4 \\
\hline & 参加者数 & .091 & +7 \\
\hline \multirow[t]{8}{*}{ AIBO の動き } & AIBO-Master の AIBO への接触 & -.146 & -1 \\
\hline & AIBO-Master の AIBO への視線 & .203 & -4 \\
\hline & 高齢者の発声 & -.175 & -4 \\
\hline & 高齢者の $\mathrm{AIBO}$ への接触 & -.129 & -4 \\
\hline & 高齢者の AIBO への視線 & .372 & 0 \\
\hline & 施設職員の発声 & .124 & +4 \\
\hline & 施設職員の $\mathrm{AIBO}$ 一の視線 & .220 & +1 \\
\hline & 参加者数 & .311 & +7 \\
\hline \multirow[t]{2}{*}{ AIBO-Master の発声 } & 高齢者の発声 & -.082 & +2 \\
\hline & 高齢者の AIBO への視線 & .115 & -2 \\
\hline \multirow[t]{2}{*}{ AIBO-Master の AIBO への接触 } & 高齢者の発声 & -.093 & -2 \\
\hline & 高齢者の AIBO への視線 & .113 & +5 \\
\hline \multirow[t]{3}{*}{ AIBO-Master の AIBO への視線 } & 高齢者の発声 & -.180 & -3 \\
\hline & 高齢者の AIBO への接触 & -.353 & +5 \\
\hline & 高齢者の AIBO への視線 & .367 & 0 \\
\hline \multirow[t]{3}{*}{ 施設職員の発声 } & 高齢者の発声 & .106 & 0 \\
\hline & 高齢者の AIBO への接触 & -.188 & +7 \\
\hline & 高齢者の AIBO への視線 & .194 & -7 \\
\hline 施設職員の AIBO への接触 & 高齢者の発声 & -.099 & -1 \\
\hline \multirow[t]{3}{*}{ 施設職員の AIBO への視線 } & 高齢者の発声 & -.155 & 0 \\
\hline & 高齢者の AIBO への接触 & .133 & +3 \\
\hline & 高齢者の AIBO への視線 & .215 & -1 \\
\hline
\end{tabular}

行指標となっていた。

2) 各測定単位における行動パターンの度数分布 1 測 定単位における 12 項目の数值全体を 12 桁の数字とみな し, 2 進法で換算し, 参加者群の「集合的行動」のパター ンを析出した。第 1 セッションにおける行動パターンの 度数分布を表したものが Figure 2, 第 13 セッションにお ける度数分布が Figure 3 である。

度数の最大值が異なるものの, 一見して, 両セッショ ンにおける行動パターンが類似していることが見受けら れる。原理的には, 2 の 12 乗パターンあるはずの行動が, 両セッションで凡そ似た形になっているのは注目に值す ると言えよう。
両セッションで最も頻度が高かった行動パターンは, 『AIBO の動き有り, Masterの発声・AIBO 一の視線有り， 参加者の視線・発声有り, スタッフの発声・視線有り, 参 加者多し（行動パターンの 2 進法表記 : 1755)』というも のであった。即ち,「AIBO の動きと共に, 参加者群が AIBO を見て会話を行う」という行動パターンが, 両セッ ションを通して多く見られたことを示している。またこ のパターンは，第 1 セッションでは全体の $3.1 \%$ を占める に留まったが，第 13 セッションでは，全体の $6.9 \%$ 占 めていた。これは, 回を重ねた結果, RAA 時における参 加者群の「集合的行動」が定型化されたことを示してい ると言える。 


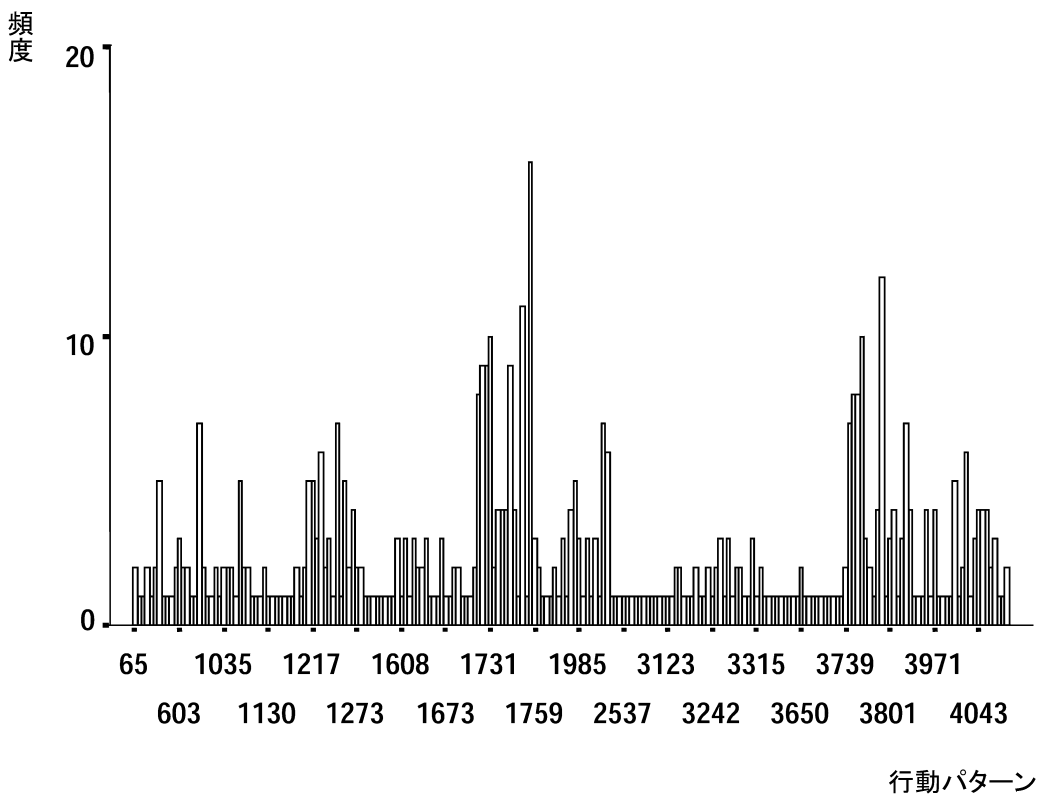

Figure 2. 2進法に基づく参加者群の行動パターン：RAA第1セッション

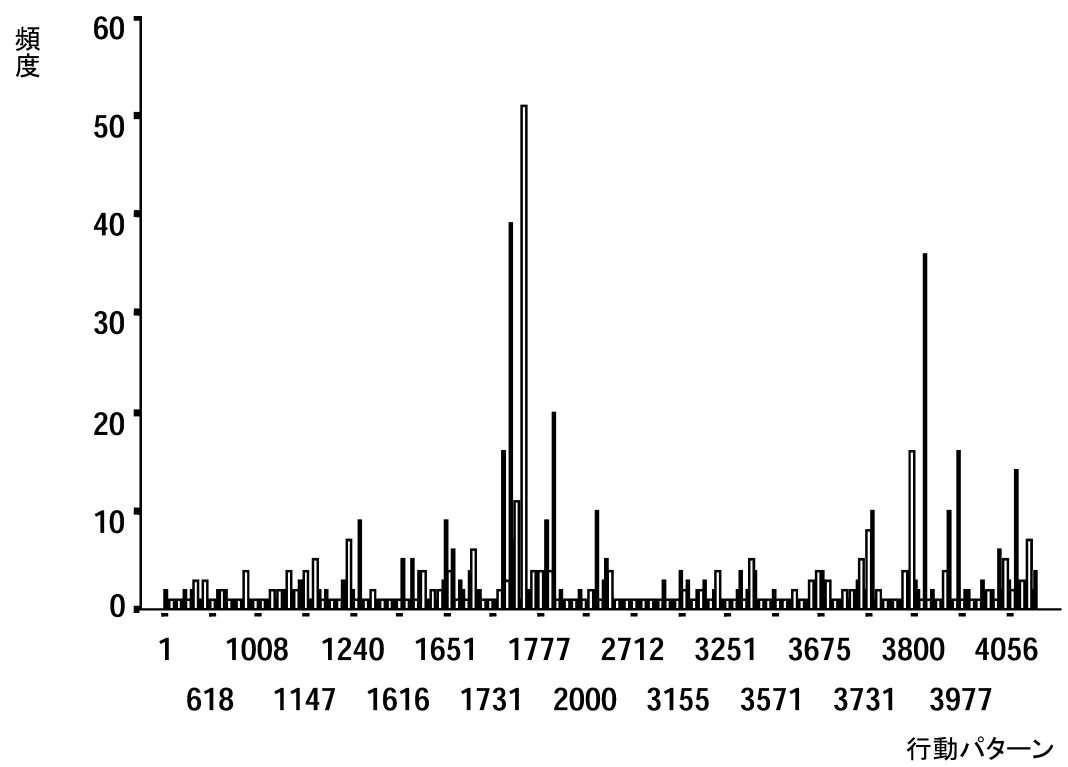

Figure 3. 2進法に基づく参加者群の行動パターン：RAA第13セッション

3）両セッション中における各行動カテゴリーの生起 率 再定義後の数值に基づき, セッション全体を通じて の, 各行動カテゴリーの生起率を算出した。第 1 ・第 13 セッションでの生起率を表したものが Figure 4 である。

第 13 セッションでは, 高齢者（参加者）の AIBO への 接触・視線, 施設職員 (スタッフ) の発声・AIBO への視
線, AIBO-Master の発声, の 5 項目で, 行動の生起率が 増加した。この結果は, 第 13 セッションの方が, 第 1 セッションと比べて, 参加者群が, 言語的・非言語的な 交流を活発に行ったことを示していると言える。

2-2. 定性的分析 定性的データの分析により, Kホーム における RAA の全セッションにおいて, 参加した 3 群に 


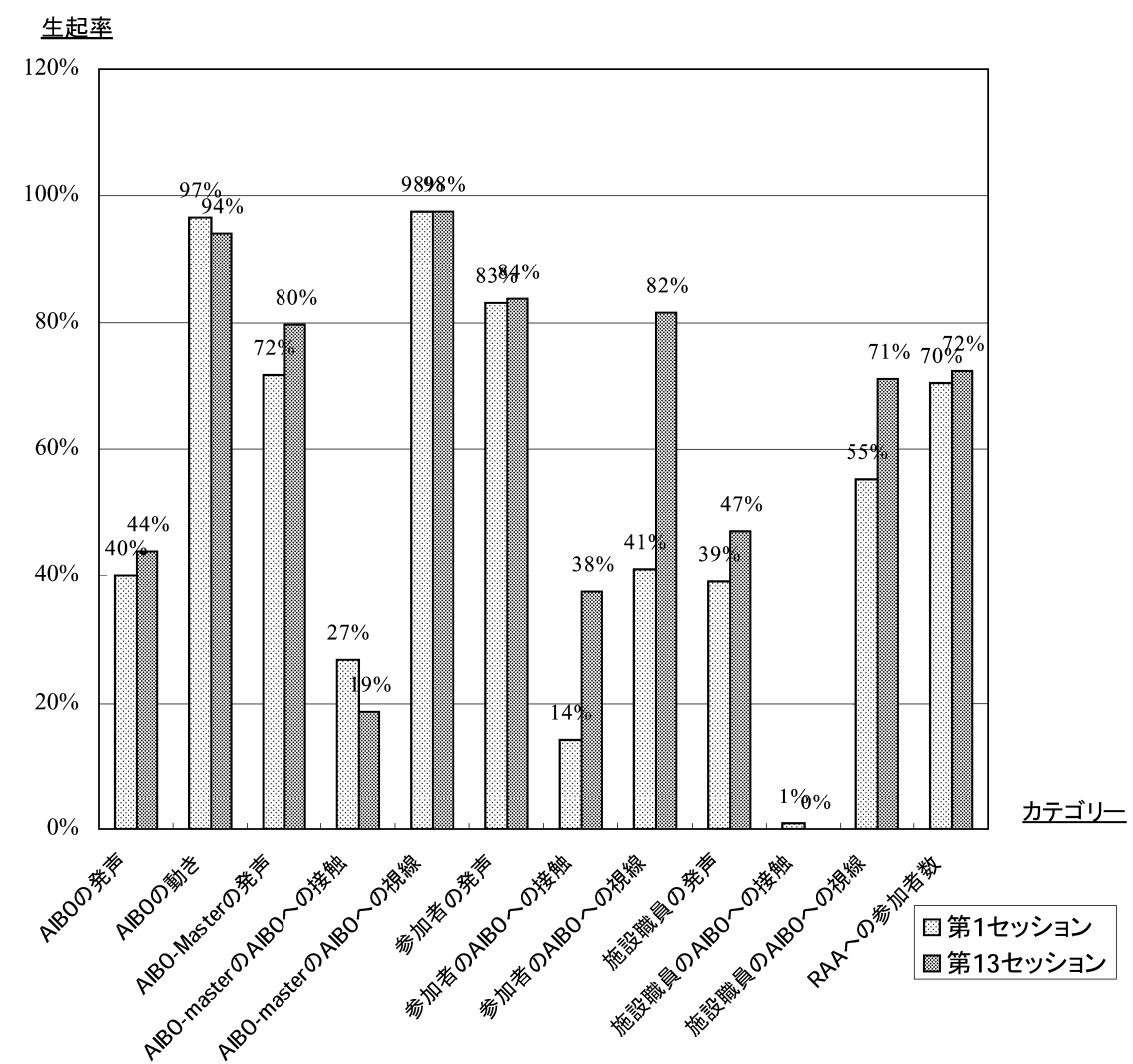

Figure 4. RAAセッション中における各行動カテゴリーの生起率 : 第1セッションと第13セッション

様々な特徵的な「反応」を見出すことができた。以下，参 加者群ごとの挙動を整理して述べる。

1) 対象者の「反応」 $\mathrm{K}$ ホームの入所者は, 誰も $\mathrm{AIBO}$ を直接見たことがなく，また AIBO のようなペット型ロ ボットの存在そのものも知らない方が多かった。このた め, $\mathrm{K}$ ホームでの RAA 導入時には, 対象者らは AIBO に 対して，どのような対応をすればよいか，当惑している ようであった。ところが, セッションを重祃るごとに, 対 象者は AIBO に対し, 愛着反応（5-6 名）, 恐怖反応（12 名), 積極的無視 (2-3 名), 無反応 (1 名), の 4 種類の 特徵的な反応を示すようになった ${ }^{8)}$ 。なお, 人数に幅が あるのは，セッションによって異なる反応を示す対象者 がいたためである。以下，順に説明をする。

「愛着反応」を示したのは, RAAに参加した高齢者のう ち，5，6名であった。これらの対象者は，RAAに積極的 に参加し, AIBO との交流を楽しんだ。この反応を示す対
象者らの行動で特徴的なのは，単にAIBO を可愛がった り, AIBOに備えられた諸機能を楽しむというだけではな く, RAA セッション中に, しばしば AIBO の内的状態を 解釈し，その内容を発言していることである。例えば， AIBO が「尻尾」を振る様子を見て,「ああ, 喜んでるわ」, $\mathrm{AIBO}$ が自分以外の対象者の方を見ていると,「ああ, そっ ちの方が良いんかね」, AIBO が体や首を摇すると, 「いや じやいやじゃ言うてるわ」等, あたかも AIBOに「心」が あるかのように, AIBOの挙動に意味付けを行った。

ここで重要なのは, こうした解釈が, 必ずしも AIBO の 本来の機能とは対応していない点である。対象者らは, そ の場その場の文脈に応じて, $\mathrm{AIBO}$ の挙動に対して「勝手 に」意味づけを行いつつ, AIBO とのふれあいを楽しんだ。

「恐怖反応」を示したのは, RAAに参加した高齢者のう ち，1，2名であった。これらの高齢者は，AIBOの振る 舞いに対して恐怖を示し, AIBO-Masterが促しても, た

8）ここで言う「愛着」「恐怖」等の用語は，厳密には，心理学の専門用語における意味とは異なる。あくまでも， 一般に用いられる意味での愛着や恐怖である。 
だただ接触を固辞した。第一筆者は，こうした反応を示 す入所者には， RAA への参加を強要はしなかった。しか し, この入所者は, RAAが行われている部屋から退出す ることはなく, セッション中は, 室内の隅から, RAAの 様子を眺めていた。

「積極的無視」を示したのは, RAAに参加した高齢者の うち，2，3名であった。この反応を示した対象者らは， RAA 導入当初は, AIBO の振る舞いに非常に関心を示し, 「どうなってんのや」「見えるのかな? 」等の感想を述べ， RAAを楽しんだ（5月 25 日のVTR 記録より）。しかし， セッションを重ねるごとに徐々に $\mathrm{AIBO}$ へ関心を失っ ていき，ついには「あのロボットには進歩がない」と言 い(施設職員談)，RAAには参加しなくなった。

「無反応」を示したのは, 娛楽室に在室する高齢者 1 名 であった。この入所者は，老人性痴呆症の症状が悪化し， AIBO や AIBO-Master（第一筆者）だけではなく，施設職 員や他の入所者からの呼びかけにもほとんど反応を示さ ない状態であった。

こうした反応のうち，特に「愛着反応」を示した対象 者らが, 繰り返し RAAに参加した。対象者らは, AIBO の内的状態についての解釈を行うだけでなく, 見解を述 べ合い，その解釈を互いに承認しあうことで共有し， AIBO の振る舞いに関する短い「物語」を共同で作り, 楽 しんだ。RAAには, 時折, これら「常連」以外の高齢者 が参加することがあった。こうした「新入り」の高齢者 らは，AIBO への対応に困惑気味であったが，「常連」の 高齢者の会話を聴き，その会話を通して，AIBO への接し 方を学んでいるようであった。「新入り」の対象者は, や がて, AIBO に対して前述の 4 つの反応のいずれかを示す ようになり,「常連」同様,「愛着反応」を示した高齢者 が，繰り返し RAAに参加した。

以下，対象者らの会話例を挙げる。これは，セッショ ン開始後 30 分を過ぎ，テーブル上にある AIBO が，対象 者の方を向いてたたずんでいる様子を見た，対象者らの やり取りである（第 11 セッションの VTR 記録より）。

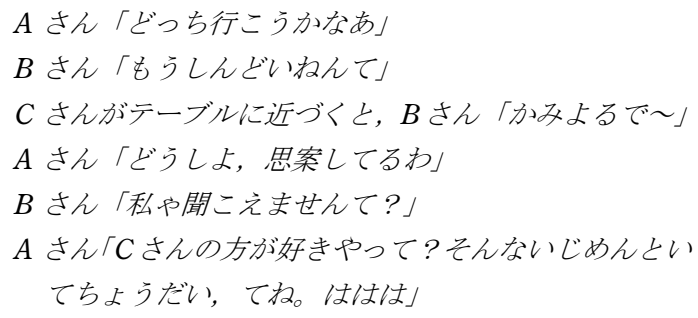

このように, RAA 実施中は, 対象者らが, その場その
場の状況や文脈に応じて, AIBO の挙動に対して「勝手 に」意味付けを行い, その解釈を述べ合い, 共同で承認 することで，RAAを楽しむ様子がしばしば観察された。

2) 職員の「反応」 RAA を導入した当初, 職員らは AIBO の挙動に感心し,「これなら（入所者の）癒しにつ ながる」(5月 25 日の観察記録より) 等と期待を寄せる発 言を繰り返した。しかし，対象者らが必ずしも全員 RAA を楽しむわけではないこと，また，RAA実施時以外の入 所者のふるまいに特に変化が見られないこと等から， RAA に対して過剰な期待を抱くことは次第になくなっ た。このことは，ケアマネージャーの発言，「（RAA は， 対象者への）『癒し』の部分ではもうひとつだ。（入所者 と会話を行う）きっかけに過ぎない」（2003 年 3 月 28 日 のインタヴュー記録より）に，よく示されている。しか し，同時に職員からは，RAAの継続が，施設におけるレ クリエーションとしての意義は高い，という発言も，第 一筆者によく寄せられた。

施設職員は, RAA セッション中, 参加者の発言を, 文 脈に即して適切に受け，会話をつなぐこと努めた。以下， RAA プログラム中における, 施設職員と入所者との会話 の一例で, AIBO-Masterが, ある対象者のひざの上に AIBO を置き，交流を促した際の場面である（第 11 セッション の VTR 記録より)。

施設職員「(AIBOが) $D$ さんのおひざの上で (笑)」

AIBO-Master 「なでてあげてくれます?」

$D$ さん「久しぶりね」(と言いながら，AIBOの頭をな でる)

施設職員「ああ，ほんとだねえ，言うてるわ」

$A I B O ：(「$ 伸び」をする)

施設職員「ああ, 気持ちいいんだわ〜。 $D$ さんのひざの 上 $」$

また, 次のような場面も見られた。これは, テーブル 上の AIBO を, 対象者や施設職員, AIBO-Master が眺め ている場面である（第 5 セッションの VTR 記録より）。

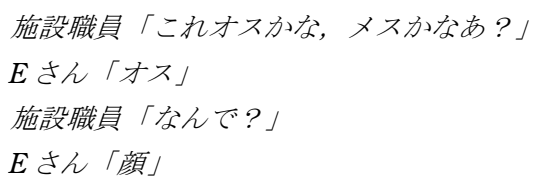


施設職員「色が黒っぽい?」

$F$ さん「感じが」

施設職員「何か言うてるねえ，何やろ？」

$F さ$ さん「れ，言うことがわからんからねえ」

こうした会話を続けることにより，施設職員は，対象 者らの $\mathrm{AIBO}$, 及び RAA への解釈を補佐し, RAAに関わ る「物語」が円滑に進行するよう務めていた, と考えら れる。

また, 施設職員は, AIBO-Masterに対し, RAA 中は参 加者に積極的に話しかけるとともに, AIBO の挙動の意味 を参加者に解説するよう指示した。こうした促しの理由 として, ある施設職員は，「(AIBO だけでは, 間が $)$ もた へんからねえ」と筆者に語った。

3） AIBO-Masterの「反応」RAA導入当初, AIBO-Master は, 単に AIBO の機能を対象者らに紹介し, ふれあいを 促す等, RAA プログラムの進行だけを行っていた。しか し，上述した職員の指摘を受け，AIBO-Master は，RAA のプログラム進行だけではなく, 状況に即して AIBO の 「声優」役を演じ，参加者の「物語」作りの補佐を務めた。 以下, AIBO の振る舞いをめぐる, 対象者と AIBO-Master とのやり取りの一部を紹介する。これは, AIBO が首を横 に振り，対象者の命令をなかなか聞いてくれなかった際 の一場面である（第 11 セッションの VTR 記録より）。

$G$ さん「いやじゃいやじや。ほら，知らん顔してる」

AIBO-Master厂(微笑みながら) 違う違う, これもう少 しみんなにかまってほしいってことですよ」

$G$ さん「ああそうかそうか」(と，AIBO の頭をなでる）。 「腕を組んでいきましょう(笑)」

$A I B O$ : (座ったまま両手を振る)

$G$ さん「これ何やろ?」

AIBO-Master 「『かまってかまって』て」

$G$ さん「ああそうか」(と， $A I B O$ の頭を再度なでる)。

このように, AIBO-Master は, 単に AIBO の機能説明 に終始するのではなく, 対象者の $\mathrm{AIBO}$ の挙動への解釈
を補佐し, AIBO への「心の読み取り」の手助けを行うこ とで, AIBO や RAA をめぐる「物語」の生成に寄与した。

\section{考察}

本研究で行った定量的・定性的分析の結果, K ホーム での RAAにおける参加者群の相互作用の特徵がいくつか 示された。定量的分析では, 3 種類の分析手法を開発・実 施し, RAA 時における参加者群の「集合的行動」のパター ンを描出した。各行動カテゴリー間の交差相関の結果, $\lceil\mathrm{AIBO}$ の動き」が, 参加者群の「AIBO への視線」の先行 指標となっていたことが示された。ところが, 参加者, 特 に対象となった高齢者の「発声」については, AIBO の挙 動が先行指標となっていなかったばかりか, 第 1 セッショ ンでは AIBO-Master の発声, 第 13 セッションでは施設職 員の発声が，わずかに先行指標となっていただけであっ た ${ }^{9)}$ 。しかしながら, セッション中の「集合的行動」の パターンを描出した 2 つ分析では, 参加者が活発に「会 話」を行っていることが示された。回を重ねた後の方が， RAA 実施中における参加者群の行動パターンが定型化し たことが示されるとともに, 第 13 セッションの方が, 各 参加者群は, 言語的・非言語的な交流をより活発に行い, 積極的にRAAに参加したことが示された。定量的分析の 結果から示唆されるのは, RAA プログラム内で最も頻繁 に生起したのは, 参加者群の「会話」であること, さら に, その会話は, 観察されうる特定の行動（例えば AIBO の挙動）が契機になっているのではなく, むしろ, 参加 者の会話そのものが, 次の会話を生むきっかけになって いること，であると考えられる。

一方, 定性的分析の結果, RAAに繰り返し参加した対 象者が, AIBOの行動に対して繰り返し「心の読夕取り」 を行い, AIBOの行動に関わる「物語」を語り合う様子が 観察された ${ }^{10)}$ 。対象者らは, RAAにおいて, AIBO の本 来の機能そのものではなく, むしろ対象者ら自身が産み 出した「物語」（浅野，2001）を楽しんでいたと考えられ る。このことは, AIBO をめぐる RAA 参加者の会話が, 他の参加者の「解釈」を受けて進展していることからも 示されている。AIBOの「心」的状態の解釈が他者の「共

9）これらの結果は，K ホームにおける既存の集合性と関連していると考えられる。施設職員へのインタヴューの 結果，Kホームでの通常のレクリエーションのほとんどが，職員らによって企画されたものであり，その進行 に際しても，職員が主導する形をとっているという話を聞き取った。高齢者や施設職員らの日頃のやり取りに 関する暗黙かつ自明の前提が，RAAをめぐる「集合的行動」「コミュニケーション」に影響を与えることは，理 論的に十分に予想されうる。

しかし，本研究では，施設の日常生活に対して参与観察を行ったが，RAA 実施場面と同程度の精度で分析で きるほど, 詳細なデータは収集していなかった。施設の既存の集合性と, RAA 実施場面での物語生成との関連 については，理論的可能性を示唆するに留め, 詳細な検討は今後の課題としたい。 
同的承認」を経ることで, その解釈が, 徐々に, AIBO を めぐるく異質性＞における「暗黙かつ自明の前提」となっ ていく。その結果, 繰り返し RAAに参加した人々にとっ て， RAA というく異質性>は，Kホームで生活における 「楽しい時間」という, もう 1 つの「現実」, 即ち「物語」 として構築された。この「物語」は，RAAをめぐる新た な暗黙かつ自明の前提となり, その後の「心の読み取り 一解釈の共同的承認一物語生成」のプロセスの基盤と なっていった。このように, $\mathrm{K}$ ホームでの RAA では, 参 加者が，RAAをめぐる「物語」を共同で構築すると共に， 自らが構築した「物語」によって，その「集合的行動」 「コミュニケーション」が規定されるという過程が見られ た。

最も重要なのは, 施設職員, AIBO-Master を含む参加 者群全体が，AIBO の挙動に関寸る解釈の「共同的承認」 （麻生，1996）に関わり，RAAに関する「物語」が共同で 構築していったことであろう。こうした「物語」が生成 された結果, 筆者らの実施した RAA は, K ホームの入所 者及び施設職員から歓迎されることになり，曲がりなり にも約 10 ケ間継続することが可能になったと言える。

長期にわたって RAA の実施が可能になり, また継続し て参加した入所者ら・施設職員らが，RAAを楽しむこと ができたのは，RAA 実施中における参加者群の「集合的 行動」の特徵, 即ち, 「心の読み取り」を契機とする「物 語の共同的承認」という営みに起因すると考えられる。本 事例では, 参加した入所者は, AIBO の振る舞いに対し て,「心の読み取り」に代表される様々な解釈を行ったこ とが観察された。そうした解釈は, 場を同じくした他の 参加者によって「共同的に承認」されることで, 初めて 「現実」となったと考えられる。つまり，ある参加者の解 釈が，他の参加者によって承認されることで，「RAAの 場」という「物語」が生成されることとなった。

本事例で観察された，RAAにおける参加者らの「集合 的行動」の特徽, 即ち, 「心の読み取り一解釈の共同的承 認一物語の生成」というプロセスは, 必ずしも, RAAに の夕観察されるものではないだろう。ペットとその飼い 主との相互作用を検討した藤崎 (2002) の先行研究から も示唆されるように, おそらく, 同様の「集合的行動」 は, 動物を「触媒」とするケア実践である動物介在療法 においても観察されるだろう。しかし，RAAの事例では，
「触媒」であるペット型ロボットの「不完全さ」ゆえに, 参加者らの「心の読夕取り一解釈の共同的承認一物語の 生成」という「集合的行動」が, より観察されやすかっ たと考えられる。

本事例において, RAAの参加者が, AIBO というペッ ト型ロボットの振る舞いに対して「心の読み取り」を行 うことができたのは，さしあたっては，AIBOの「あたか も生きているような」振る舞いに起因すると言えるかも しれない。しかし，そこで為された $\mathrm{AIBO}$ ての心」の 措定, 即ち, AIBOに対する「心の読み取り」という営み は，参加者一個人と AIBO との二者関係では，たちまち 崩壊してしまう危ういものであったと考えられる。それ は, 周囲の人々がその解釈を補佐しなければ, 対象者が AIBO とのふれあいに「飽きてしまう」ことや，そのこと を見かねた施設職員がAIBO-Masterにもっと頻繁にAIBO の振る舞いに解釈を施すよう促したことからも伺える。 $\mathrm{AIBO}$ という新奇な存在をめぐる, <異質性 >の生成過程 は,「心の読み取り」という, AIBOに「心」を付与する 営みが, 参加者全員によって共同的に承認されることに よってのみ，辛うじて生成したものであったと言えよう。

付言すれば，本事例の中で生成された RAA ぬめ゙る 「物語」は，あくまでも絶対的なものではなく， RAA とい う場の中で，一時的に効力を有するものであったと言え る。このことは, RAA 終了後に入所者から労いの言葉を かけられるのが，AIBO ではなく AIBO-Master（第一筆 者）であったことからも伺える。参加者らは, AIBO をめ ぐる RAA 時の「集合的行動」(例えば, AIBO の挙動に関 する発話, 等), 及び「コミュニケーション」（例えば, ペット型ロボットはかわいいものであるという暗默の前 提，等）を楽しみつつも，それが「もうひとつの現実」で あることに自覚的であったと考えられる。それゆえ, RAA プログラムが終了するや否や, AIBO をめぐる「集合的行 動」(例 : AIBO の挙動への解釈) 及び「コミュニケーショ ン」(例 : RAA はペット型ロボットと遊ぶ場である, とい う規範）から, AIBO-Master をめぐる「集合的行動」（例： AIBO-Master への労いの言葉）及び「コミュニケーショ ン」（例：レクリエーション後には，実施者にお礼を言う べきである, という規範）へと，入所者は移行したので あろう。

しかし，だからと言って筆者らは，RAAが，施設にお

10）観察する視点をより巨視的にすれば，「恐怖反応」「積極的無視」「無反応」などを示した入所者もまた，RAAを めぐる「集合的行動」・「ミュニケーション」の生成に関わっていたことは言うまでもない。ただ，本考察で は, RAA 実施中における, ペット型ロボットをめぐる参加者の相互作用に焦点を置いたため, RAAに積極的に は参加しなかった人々の行動については，最小限の説明に留める。 
けるケア (に関わる実践) として無効であると主張する わけではない。むしろ，RAAが，約 10ケ月間にわたり， 毎週 1 回 1 時間だけでも, AIBO をめぐるく異質性>生成 の場たり得たことにこそ, 注目寸べきである。 K ホーム で RAA プログラムが導入された結果, 入所する高齢者に とっては, 週に 1 回, ペット型ロボットをめぐって楽し い会話を行える場が設けられることとなった。また, 施 設職員にとっては，入所者と会話をするきっかけが，さ らにもう 1 つ増えることとなった。RAA の実施は, K ホー ムにおける既存の集合性とは異質な, 新しい「集合的行 動」「コミュニケーション」を生成する契機となっていた。 RAA をめぐる「物語」は，Kホームの既存の集合性にとっ て,「もらひとつの現実」(<異質性〉) であったと考え られよう。

\section{ロボット介在活動の実践プログラムに向けて}

最後に, RAA の実践プログラムに向けての提言を行う。 本研究で得られた知見, 即ち, RAA 実施中の参加者の相 互作用が，「物語の共同的承認」によって特徴付けられる ということは, RAA 実践のプログラム開発にも，重要な 示唆を与えると考えられる。「ロボット」介在活動をめ ぐっては，ともすれば「主役」であるロボットの性能に 注意が向きがちである。しかし，RAA は，個人とロボッ 卜との単線的な相互作用で捉えきれるものではなく, RAA に参加寸る人々全員の相互作用によって成立寸る, すぐれて集合的な営みであると考えられる。「物語の共同 的承認」によって，RAA が成立するならば，重要なのは ロボットよりもむしろ, その物語を承認してくれる人物, 即ち本事例の AIBO-Master や施設職員のような人々であ ろう。RAAが，レクリエーションとして，ひいてはケア として成功するかどうかにとって， RAA をめぐる物語の 共同的承認に携わる人物の存在がきわめて重要であると 考えられる。物語の共同的承認者 (例えば, AIBO-Master) は，対象となった人々の傍らに寄り添い，ロボットをめ ぐる「語り」を注意深く聴き取ることが求められる。そ の際, 承認者は, 対象者自身の物語を尊重・受容し, そ の文脈に沿う形で, 新たな物語を, 対象者らと協働で構 築する必要がある。そのためには, 承認者は, 単にRAA 実施場面での文脈に注意するだけではなく, 対象者らを 包むより大きな集合性に注目し，その集合性との整合性 を取りつつ，物語を生成する必要があると言えるだろう。
最後に, 動物介在療法の実践と比較した RAA プログラ

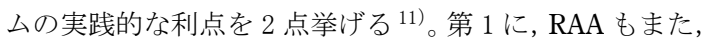
動物介在療法と同様に，ケアにおける新奇の「集合的行 動」「コミュニケーション」を生成しうる，ということで ある。現状では，ペット型ロボットの振る舞いは，生き た動物と比較して未だ「不完全」であると言える。その 「不完全さ」ゆえに, RAAを継続するためには, 直接の対 象者だけではなく, 周囲の人々による「手助け」が必要 となる。即ち, RAA に参加する人々は, 「心の読み取り一 解釈の共同的承認一物語の生成」というプロセスを, 共 同で行い続けなければならない。しかしながら，このよ うな一見手間のかかる性質をペット型ロボットが有して いること，また，RAAに関わる人々全員が「心の読み取 り一解釈の共同的承認一物語の生成」というプロセスを 行い続けなければならないということは，＜異質性＞を 生成するためにはむしろ利点となっていると言える。ケ アの場面におけるく異質性>の生成は, 現行のケアの手 法（即ち, 既存の集合性に則ったケアの手法）とは別の, 異なるケアの手法の可能性を明らかにすることともな る。RAAの実践は, 単に「ロボットとのふれあい」以上 に, <異質性>の生成を通した, より豊かなケアの手法 の開発につながりうる，と考えられる。

第 2 に, ペット型ロボットは, 動物と比して, 維持費・ 世話等のコストが安価である, という点である。もちろ ん,「動物の世話」が，人間に対寸るケアにおいて有効で あることは, これまでの動物介在療法をめぐる先行研究 でもしばしば主張されているが（e.g., Levinson \& Mallon, 1997)，例えば医療・福祉施設などの限られた環境の中で は, 高コストのプログラムを適用し続けることは困難で あろう。このため, より安価なプログラムである RAA は, 導入・実施共に, 動物介在療法を比べて容易であると言 える。重要なのは, 本研究での知見にもあるように, ペッ ト型ロボットの挙動の意味が, RAAに参加した人々自身 が生成する「物語」によって決定される, ということで ある。ロボットを用いるとは言え RAA では, 生成される 「物語」の内容によっては, ペット型ロボットを「世話」 するような現実を構成することは可能であろう。

本研究では, RAAの長期にわたる実践, 及び参与観察 によって, RAA 中の参加者群の相互作用の特徵を量的・ 質的に示寸ことができた。特に，分析手法の開発により， RAA 実施中の参加者群の「集合的行動」を，わかりやす

11）横山（2002）は，動物と比したペット型ロボットの利点として，「(病原体などを保持しないという意味で）清 潔である」「(予想外の行動をしないという意味で）安全である」「動物のストレスを考えなくても良い」「プロ グラム可能である」の 4 点を挙げている。 
く示すことができた。また, 分析結果より, RAA 参加者 群の「集合的行動」における，ペット型ロボットに対す る「心の読み取り」, 及びその解釈の「共同的承認」とい う特徵が考察され, RAA の場における物語の生成・維持・ 変容の重要性が示された。さらに, RAA プログラムの実 践に際しては, 物語生成の補佐を為す, AIBO-Master や 施設職員など, 直接の対象者以外の人々の重要性も示唆 された。本研究で検討された, ロボットという新奇な存 在をめぐる集合性の変容過程に関する知見が，今後の RAA の研究及び実践に貢献することを願ってやまない。

\section{引 用 文 献}

浅野智彦 2001 自己への物語論的接近 勁草書房 麻生 武 1996 ファンタジーと現実 金子書房 Braitenberg, V. 1984 Vehicles: Experiments in synthetic psychology. Kunstliche Wesen. 加地大介 訳 模型は 心を持ちうるか : 人工知能・認知科学・脳生理学の 焦点 哲学書房 1987

土肥健純 1996 コンピュータ外科におけるロボット技 術 日本ロボット学会誌，14(5)，24-27.

Emerson, R. M., Fretz, R. I., Shaw, L. L. 1995 Writing ethnographic fieldnotes. The University of Chicago Press, Chicago. 佐藤郁哉 - 好井裕明 - 山田富秋 訳 1997 方法としてのフィールドノート 新曜社

藤江正克 1996 歩行支援ロボット 日本ロボット学会 誌, 14(5)， 16-19.

藤本浩志 1996 多機能動力義足 日本ロボット学会 誌, 14(5), 20-23.

藤崎亜由子 2002 人はペット動物の「心」をどう理解 するか : イヌ・ネコへの言葉かけの分析から 発達 心理学研究, 13(2), 109-121.

藤崎正昭・内山 隆 1996 高齢者・障害者用食事搬送 自動ロボットシステム 日本ロボット学会誌, 14(5), 7-11.

藤田雅博 1999 ペット型ロボットの感性表現 日本口 ボット学会誌，17(7)，33-37.

Gergen, K. J. 1999 An invitation to social construction Sage. 橋本智己・浜田利満・赤澤とし子 2001 観察法による, 人間のロボットと動物に対する行動様式の比較検討 第19回日本ロボット学会学術講演会, 915-916.

橋野 賢 1996 生活介護ロボット 日本ロボット学会 誌， 14(5)，2-6.

廣松 渉 1989 表情 弘文堂思想選書

岩本隆茂・福井 至 共編 2001 アニマル・セラピー の理論と実際＼cjkstart培風館
加藤一郎 1993 リリスボット一生活支援ロボット一の

構想 日本ロボット学会誌，11(5)，14-17.

加藤謙介・渥美公秀 2002 動物介在療法の導入による 集合性の変容過程 : 老人性痴呆疾患治療病棟におけ るドッグ・セラピーの事例 実験社会心理学研究, $41(2), 67-83$.

子安増生・木下孝司 1997 <心の理論＞研究の展望 心理学研究, 68(1), 51-67.

Levinson, B. M., Mallon, G. P. 1997 Pet-oriented child psychotherapy second edition. Charles C. Thomas Publisher. 川原隆造 監修 松田和義・東 豊 監 訳 子どものためのアニマルセラピー 日本評論社 2002

野口裕二 2002 物語としてのケア:ナラティヴ・アプ ローチの世界へ 医学書院

楽学舎 編 2000 看護のための人間科学を求めて ナ カニシヤ出版

佐部浩太郎・藤田雅博 2000 エンターテインメントロ ボットの商品化日本ロボット学会誌，18(2)，185187.

柴田崇徳 2000 感情を持つかのような人工システム： 人工物を中心に 日本ファジィ学会誌, 12(6), 34-43. 柴田崇徳 1999 人の心を癒すメンタルコミットメント ロボット 日本ロボット学会誌, 17(7), 29-32.

白井良明・浅田 稔 2001 身近になるロボット 大阪 大学出版会

杉万俊夫 2001 グループ・ダイナミックスの理論 中 島義明 編 現代心理学 [理論] 事典 朝倉書店 pp. 641-659.

杉万俊夫（編著） 2000 よみがえるコミュニティ： フィールドワーク人間科学 ミネルヴァ書房

手嶋教之 1996 食事支援マニュピレータとその要素技 術 日本ロボット学会誌, 14(5), 12-15.

Turing, A. M. 1950 Computing machinery and intelligence. Mind, 59, 433-460.

上野直樹・西坂 仰 2000 インタラクション：人工知 能と心 大修館書店

Wada, K., Shibata, T., Saito, T., \& Tanie, K. 2002 Psychological and Social Effects to Elderly People by Robot Assisted Activity at a Health Service Facility for the Aged SCIS \& ISIS 2002.

Weizenbaum, J. 1976 Computer power and human reason: From judgment to calculation. W. H. Freeman. 秋葉忠 利 訳 コンピュータ・パワー：人工知能と人間の 理性 サイマル出版会 1979 
横山章光 1996 アニマル・セラピーとは何か NHK ブックス

横山章光・玉井伸哉・太田清利・高橋早苗・長谷川妙子・ 赤西芳樹 - 中村和彦 - 太田光明 2001 小巟病棟に おける4足歩行型ロボット（AIBO）によるRAA（ロ ボット介在活動）の試行（総合病院の中でAATを始
めることは可能か? 一中間報告その2） 人と動物の

関係学会第7回学術大会予稿集, 40 .

横山章光 2002 ロボットを活用した精神医療の可能 性 : アニマルセラピーの視点から 最新精神医学, 7(5), 439-447.

\title{
Generating process of stories in robot assisted activity: \\ A case study of Robot Assisted Activity with pet-type robot at a for-profit nursing home
}

\author{
KensuKe Kato (Osaka University) \\ TомонiDE ATSumi (Osaka University) \\ KATUYA YAMORI (Kyoto University)
}

The present study investigated the case of robot assisted activity (RAA) for elderly inpatients, and examined RAA as co-constructing process of stories about the robot. We carried out RAA program with pet-type robot for elderly people in the for-profit nursing home, and conducted participant observation. We collected quantitative and qualitative data concerned with the participants' behaviors during RAA program, and examined the features of the participants' interaction and narratives. As a result of these analyses, we could observe that the participants generated the "story of RAA" based on the participants' own narratives. The residents who joined in RAA repeatedly conducted "mind reading" toward pet-type robot, and narrated the "story" about the robot's behavior with each other. The participants "approved the story in cooperation" (Asao, 1996). Moreover, not only the elderly subjects but also the staff members and the author joined in the constructing process of the story. We could conclude that RAA was a co-constructing process of heterogeneity (Sugiman, 2001) based on the participants' narratives.

Key Words: robot assisted activity, pet-type robot, heterogeneity, mind reading, generating process of stories 